\title{
POLITIKK
}

SKANDINAVISK TIDSSKRIFT

FOR INTERNASJONALE STUDIER

Årgang 76, Nummer 3, side 159-182, 2018, ISSN 1891-1757, www.tidsskriftet-ip.no, Publisert september 2018

\section{Ambivalent og historieløst? Norske avisers dekning av norsk militært nærvær i Syria og Irak}

\author{
Rune Ottosen \& Belinda Jørandli Rudsengen \\ Høgskolen i Oslo og Akershus (OsloMet)
}

\begin{abstract}
Sammendrag
Denne artikkelen beskriver hvordan de fem norske avisene VG, Aftenposten, Klassekampen, Dagsavisen og Dagbladet dekket forespørselen fra USA om deltagelse i krigen mot IS i Syria i 2015, sammenlignet med dekningen av beslutningen om å sende norske soldater for å trene irakiske styrker i krigen mot IS i Irak i 2014. Tidspunktet for analysen er 15. september-30. november 2014 (Irak) og 8. desember 2015-22. januar 2016 (Syria). Metoden er kvantitativ innholdsanalyse basert på vurdering av om artiklene er «negative uten FN-mandat», "negative uansett», "positive med FN-mandat", "positive uansett», «nøytrale» eller «andre». Det er også gjennomført en sjangeranalyse med vekt på forskjeller mellom ledere, kommentarer og nyhetsartikler. Endelig ble det gjennomført en kvalitativ analyse av lederartiklene ved hjelp av kritisk diskursanalyse. Hypotesene er at norske aviser vil være mer negative til deltagelse i Syria enn i Irak, og enn ved tidligere hendelser som deltagelse i utenlandsoperasjoner i Jugoslavia (1999), Afghanistan (2001) og Libya (2011). Undersøkelsen viser at hypotesene bare delvis ble bekreftet.
\end{abstract}

Nøkkelord: IS · krig mot terror $\cdot$ Syria $\cdot$ Irak $\cdot$ folkerett

\section{Innledning}

Norske mediers dekning av kriger og konflikter har vært preget av konsensus og støtte til den rådende sikkerhetspolitiske tankegangen i landet (se f.eks. Ottosen 2001, Helseth 2007). Dette fører ofte til manglende debatt i mediene rundt sentrale temaer - som blant annet hvorvidt og hvordan Norge skal delta i ulike kriger.

\footnotetext{
^Kontaktinformasjon: Rune Ottosen, rune@oslomet.no

(C2018 Rune Ottosen og Belinda Jørandli Rudsengen. This is an Open Access article distributed under the terms of the Creative Commons Attribution 4.0 International License (http://creativecommons.org/licenses/by/4.0/), allowing third parties to copy and redistribute the material in any medium or format and to remix, transform, and build upon the material for any purpose, even commercially, provided the original work is properly cited and states its license. Citation: Rune Ottosen og Belinda forandli Rudsengen (2018). Ambivalent og historieløst? Norske avisers dekning av norsk militcert nervaer i Syria og Irak, 76:159-182. http://dx.doi.org/10.23865/intpol.v76.658
} 
Mediedekningen av Norges bidrag i Libya-krigen i 2011 er et eksempel på hvordan en rekke toneangivende norske medier unnlot å se bidraget i et kritisk lys før etter det ble mer legitimt å hevde at man brøt folkeretten ved å bidra til regimeskifte i landet (Ottosen, Slaatta og Øfstli 2013). Dette er bare ett eksempel på hvordan mediene kan sies å svikte sitt samfunnsoppdrag ved ikke å belyse og drøfte ulike sider ved kritiske avgjørelser om militære bidrag.

I 2014 og 2015 ba USA om at Norge skulle bidra i krigen mot IS i henholdsvis Irak og Syria. Denne artikkelen er basert på en undersøkelse av fem store norske avisers dekning av disse to forespørslene. Kan mediene sies å ha lært av tidligere ukritisk dekning, og med det ha hatt en mer kritisk og mangfoldig dekning av spørsmålet om norsk militær deltagelse i krigen mot IS? Dette er blant spørsmålene denne undersøkelsen søker svar på.

Problemstilling for undersøkelsen er: Har norske papiravisers dekning av norske militære utenlandsbidrag endret seg de siste årene?

Denne vil undersøkes mer konkret gjennom å se på hvordan fem norske papiraviser dekket forespørselen fra USA om å delta i kampene mot IS i Irak, sammenlignet med hvordan de dekket et mulig norsk bidrag i Syria. Dekningen av et mulig militært bidrag i Syria vil også sees opp mot hvordan avisene historisk sett har dekket norske militære utenlandsbidrag i Libya, Kosovo og Afghanistan.

\section{Den offentlige samtalen om krig og fred}

Det har tradisjonelt vært stor grad av konsensus blant norske politikere om sikkerhets- og utenrikspolitikk i norske medier (Ottosen 2001). Militære aksjoner i regi av NATO etter at "out-of area»-politikken ble etablert i 1997-1998, har fått bred støtte både blant politikere og medier (Helseth 2007). De kritiske røstene har kommet til uttrykk i debattinnlegg og kronikker, spesielt i nisjeaviser som Klassekampen og Ny Tid. Under den kalde krigen var det en del av NATOs strategi at man skulle begrense eventuelle militære operasjoner til Europa. Etter at Warsawapakten ble oppløst i 1991, så NATO seg om etter en ny rolle. Dette paradigmeskiftet ble i liten grad diskutert i mediene på en kritisk måte (Linneberg 2001). I den statsvitenskapelige litteraturen har blant annet Iver B. Neumann pekt på at Norge historisk har en krigstradisjon som ikke hører hjemme i norske politikeres bestrebelser på å framstå som en "fredsnasjon» (Neumann 2004). Nina Græger har vist at endring i norske militære operasjoner fra fredsbevarende bidrag i FN-regi til mer offensive operasjoner i tråd med NATOs doktrine, er en logisk endring av NATOs strategi (Græger 2015). Øystein Haga Skånland har vist at Norges selvbilde som fredsnasjon har blitt en integrert del av hvordan Norge begrunner og forsvarer sin utenrikspolitikk (Haga Skånland 2009). Vi vil i denne artikkelen vise hvordan norske politikere ser ut til å ha problemer med å tilpasse sin retorikk om Norge som fredsnasjon til de faktiske endringene på bakken. Siden mediene er tett på politikernes retorikk og historisk har hatt problemer med å utfordre norsk sikkerhets- og utenrikspolitikk, kan vi få 
problemer med å etablere en informert opplyst samtale om konsekvenser av å delta i militære utenlandsoppdrag (Ottosen 2001).

Kristoffer Egeberg går i sin bok Fredsnasjonen Norge gjennom alle norske militære utenlandsoppdrag med og uten $\mathrm{FN}$-mandat. Etter å ha intervjuet samtlige norske utenriks- og forsvarsministre de 20 siste årene er et hovedfunn at den viktigste motivasjonen for å bidra militært utenfor landets grenser, er å tilfredsstille ønskene til vår viktigste allierte USA. Egeberg viser også at de norske soldatene som deltar i disse operasjonene, føler seg lite sett av norske politikere. Politikerne får kritikk for å være mer opptatt av sitt eget selvbilde som fredsskapere enn soldatenes faktiske krigføring. Når soldatene deltar i skarpe oppdrag med fare for egne liv, føler de seg sviktet av politikere (Egeberg 2017). En grunnleggende tese i denne artikkelen er at politisk retorikk og "merkevarebygging» i større grad enn prinsipielle spørsmål knyttet til folkerett og menneskerettigheter preger den offentlige samtalen. Som medieforskere er vi her særlig opptatt av medienes ansvar for å bidra til en mer opplyst samtale.

\section{Norske utenlandsoperasjoner fra Kosovo til Afghanistan}

NATOs «out-of area»-politikk ble for første gang satt på prøve under operasjon Allied Force med bombing av Jugoslavia i 1999. Da var det så å si ingen stortingspolitikere, bortsett fra et par av SV-representantene, som uttrykte motforestillinger mot norsk deltakelse i operasjonene (Helseth 2007). Et eksempel på at det likevel forekom kritisk journalistikk, var Aftenpostens kritiske søkelys på saksbehandlingen i Stortinget forut for bombingen. Her ble det avdekket at det ikke forekom skriftlig kommunikasjon mellom Stortinget og Regjeringen i sakens anledning. Bare én partigruppe foretok en formell avstemning om tilslutning til aksjonen, og ingen formell avstemning fant sted i Stortinget som godkjente Norges deltagelse (Ottosen 2002: 38).

Etter terroranslaget mot USA 11. september 2001, uttrykte norske stortingspolitikere sin støtte til den såkalte "Global War on Terror»-doktrinen (GWT). Et forsiktig ønske fra den norske utenriksministeren Torbjørn Jagland om at USA måtte vise tilbakeholdenhet i sin gjengjeldelse for å skåne sivile, ble øyeblikkelig brukt av tunge amerikanske medier som Washington Post til å sette spørsmålstegn ved om norske politikere "egentlig var til å stole på». Norge kom etter dette «ut i kulden» og ble sterkt kritisert av amerikanske medier og politikere (Egeberg 2017). Etter dette var det ingen toneangivende norske politikere som ga uttrykk for tvil i sin støtte til USA (Ottosen 2009). Dermed forstummet også kritikken i mediene, et fenomen som er kjent fra internasjonal forskning.

Bennett viser at kildebruken til sentrale medier gjerne støtter opp under argumentasjonen til regjeringstalsmenn og deres pressetalsmenn (Bennett 1990:116). Kun når den politiske eliten er splittet, gir det rom for kritikk i mediene. Dette fenomenet er bekreftet i en rekke studier, og kommer også til uttrykk i en komparativ studie av dekningen av invasjonen i Irak i mange land. Europeiske medier delte seg mellom de som sluttet opp om "koalisjonen av de villige», med USA og Storbritannia 
på den ene siden, og krigsmotstanderne med Tyskland og Frankrike på den annen. Denne fløyen av motstand ble av daværende forsvarsminister, Donald Rumsfeld, foraktfullt kalt for «det gamle Europa». Men den fikk støtte av mediene i sine egne land og gjorde det mulig at også deler av britisk presse gikk mot krigen (Nohrstedt og Ottosen 2005, 2014). I Norge nedfelte denne samme splittelsen seg i ulikt syn på invasjonen blant ledende aviser som VG og Aftenposten. Tradisjonelt har disse to avisene stått last og brast med hovedlinjene i norsk sikkerhetspolitikk, men de var delt i synet på invasjonen i Irak i 2003. Aftenposten støttet Bondevik-regjeringens krigsmotstand, mens VG beklaget at Norge ikke sluttet opp om vår viktigste allierte USA (Ottosen 2009). Norges militære deltagelse i Afghanistan har i liten grad ført til omfattende politiske debatter om prinsipielle spørsmål knyttet til Norges deltagelse før Godal-utvalgets rapport ble publisert i 2016 under tittelen: En god alliert Norge i Afghanistan 2001-2014.

I mange år har heller ikke mediene bidratt til kritiske debatter av mer prinsipiell art. Flere studier av mediedekningen viser at mediene generelt $i$ liten grad viser vilje til å diskutere de folkerettslige problemstillingene knyttet til norsk deltagelse i internasjonalt organiserte intervensjoner (Ottosen 2010). Til tross for at mange har skrevet om problemer knyttet til menneskerettighetsbrudd, for eksempel om frakt av fanger fra Afghanistan til Guantanamo Bay, er norsk deltagelse ikke knyttet til en kritikk av menneskerettighetsbrudd (Rossland og Ottosen 2013).

En hypotese er at den norske dekningen har vært preget av at journalistene som dekker kriger, velger å følge de norske militære styrkene på nært hold. Forholdene er godt lagt til rette for slike valg, og for å komme til krigssoner har man gjerne måttet reise på spesielt arrangerte turer. En av konsekvensene har vært at norske mediers dekning har vært preget av elitekilder der norske politikere og militære kilder får dominere med sine perspektiver (Moen 2013, Nordby 2013). Fokuset i dekningen har i liten grad vært på situasjonen til den afghanske sivilbefolkningen (Eide og Ottosen 2013). Sammenligner vi dekningen av de norske soldatene som er blitt drept med dekningen av den afghanske sivilbefolkningens tap, danner det seg et mønster av det som Noam Chomsky kaller "verdige» og «uverdige» ofre (Chomsky and Herman 1988, Fondenes 2013). En ny kritisk dimensjon i dekningen kom først til etter at frilanseren Anders Sømme Hammer bosatte seg i Afghanistan og ved hjelp av egne kilder og et uavhengig fortellerperspektiv kunne se krigen mer fra den afghanske sivilbefolkningens ståsted (Hammer 2010).

Dette bakteppet kan være nyttig å ha med seg når vi nå skal gå mer konkret inn på hvordan norske medier forholdt seg til de prinsipielle sidene av spørsmålet om norske militære styrkers deltakelse i den Nato-ledete operasjonen i Libya, våren og sommeren 2011 (Tunander 2012).

\section{Libya-debatten - et vendepunkt?}

Mens norske toneangivende medier støttet bombingen av Libya våren 2011 både på lederplass og redaksjonelt, forekom det mer kritikk og debatt i nisjeaviser som 
Morgenbladet, Ny Tid og Klassekampen (Ottosen, Slaatta og Øfstli 2013). Høsten 2015 ble det $i$ en kort periode debatt i den norske offentligheten etter at Terje Tvedt gjennom en større artikkel i Nytt Norsk Tidsskrift med den betegnende tittelen "Tausheten om Libya» anklaget norske politikere og medier for ikke å ta innover seg hvilken skade Norge hadde bidratt med giennom å spille en ledende rolle i NATOs bombing av Libya. Tvedt skriver blant annet:

«Libya-krigen fremtrer mer og mer som et nasjonalt traume, fordi det er en ulmende erkjennelse av at gapet mellom den offentlige entusiasmen for krigen og resultatene av den avdekker sentrale trekk ved norsk mentalitetshistorie og det politiske lederskaps verdensbilder og selvbilder. Blant alle observatører er det generell enighet om at situasjonen er verre enn under Gaddafi» (Tvedt 2015).

I en påfølgende debatt i Aftenposten og Klassekampen så vi også tilløp til en debatt der folkerettslige spørsmål ble behandlet. Men nok en gang viste det seg at det var forskere som Geir Ulfstein og Cecilie Hellestveit som på kronikkplass og i leserbrev tok fatt i disse spørsmålene (Ulfstein 2015 a,b), (Hellestveit 2015), (Tvedt 2015b). I begrenset grad ble disse spørsmålene fulgt opp på redaksjonell plass av redaksjonene (Aftenposten 2014, 2015). I den påfølgende debatten i Aftenposten ble det også tilløp til en folkerettslig diskusjon som tidligere forskning har vist at har vært mangelvare $i$ mediedekningen av norsk krigføring i utlandet (Nohrstedt og Ottosen 2014).

Rune Ottosen og Sjur Øvrebø viste i en annen undersøkelse at Aftenposten i sin dekning av Syria-krisen i liten grad så sammenheng mellom den kritiserte norske krigføringen i Libya og den akselererende borgerkrigen i Syria. Dette til tross for at det er vel dokumentert at opprørere fra Libya tok med seg våpen i kjølvannet av bombingen og fortsatte krigføringen inne i Syria (Ottosen \& Øvrebø 2016), (Nohrstedt og Ottosen 2017).

Med dette bakteppet er dekningen av norske styrkers bidrag i krigen mot IS i Irak og Syria sett nærmere på i denne undersøkelsen.

\section{Hypoteser for undersøkelsen}

I lys av problemstillingen som er nevnt tidligere i artikkelen, vil vi sette fram følgende hypoteser:

1. Norske papiraviser har vært mer kritiske til et mulig bidrag mot IS i Syria enn de var til et mulig bidrag i Irak.

2. Norske aviser vil være mer kritiske til deltagelse i militære operasjoner i Syria enn de var da Norge deltok i NATO-operasjonene i Jugoslavia (1999), Afghanistan (2001) og Libya (2011).

Bakgrunnen for den første hypotesen er at det i Irak forelå en forespørsel fra den irakiske regjeringen om å bidra i kampen mot IS (Regjeringen.no 03.03.2015). Dersom Norge bestemte seg for å gå inn i den amerikanskledede koalisjonen der, ville de takke ja til denne. I Syria anerkjente den norske regjeringen i 2012 opposisjonen 
i landet som en legitim representant for det syriske folket, og stilte seg med det i praksis mot Assad (Hellestveit 2017:129-130). Dermed ville en invitasjon fra regjeringen her naturligvis ikke aksepteres. Uten noe $\mathrm{FN}$-mandat til å gå inn i landet, ville et norsk bidrag i Syria dermed komme uten noen klar forankring i folkeretten, og det kunne forventes at kritikken mot et mulig bidrag her var sterkere enn mot bidraget i Irak. Da det i desember 2015 ble diskutert om Norge skulle bidra i Syria, var det heller ikke kommet noen klare resultater i krigen mot IS i Irak. Hypotesen er også utformet med bakgrunn $\mathrm{i}$ at manglende resultater her kan ha påvirket holdningen til om man bør gå inn i nok et land.

Den andre hypotesen er utformet med bakgrunn i at det var stor politisk uenighet om hvorvidt Norge burde bidra i Syria, (Se f.eks. Klassekampen 28.06.2016). Som nevnt over var konsensusen langt større rundt norsk deltagelse i blant annet Afghanistan og Libya. Legger man Bennets teori til grunn, vil det da også kunne forventes mer kritikk og uenighet i pressen rundt norsk militær deltagelse i Syria.

Med dette som utgangspunkt vil undersøkelsen kunne bidra til å belyse om norsk presse har blitt mer kritiske til hvordan de dekker norske militære utenlandsoppdrag. Den kan også belyse om det finnes tendenser til at norsk presse tar med seg erfaringene fra utfallet av tidligere hendelser inn i dekningen av nye, lignende tilfeller. Samtidig vil den kunne bidra til at hypotesen om at norske medier har en tendens til å støtte den rådende sikkerhetspolitiske tankegangen i landet, enten styrkes eller svekkes.

\section{Metode}

For å undersøke problemstillingen har vi gjennomført en kvantitativ innholdsanalyse. Denne metoden egner seg godt til å undersøke et større materiale, for eksempel for å se hvordan en sak som helhet er blitt dekket i media, noe vi ønsket å gjøre i dette prosjektet.

Retriever er brukt som verktøy for å finne fram til artikler om temaet i de ulike avisene. For å kunne gjennomføre analysen var vi nødt til å avgrense tidsperioder, finne fram til søkeord og velge ut hvilke aviser vi ønsket å se på. Vi måtte også velge hvilke variabler vi ønsket å undersøke. I det følgende vil valgene gjort rundt disse tingene begrunnes, samt utfordringer knyttet til de ulike metodiske valgene drøftes.

\section{Caser: Irak og Syria}

Bakgrunnen for valget av tidsrom for de to casene er som følger:

Irak: 15. september i 2014 deltok utenriksminister Børge Brende på en IS-konferanse i Paris, hvor blant annet inngripen i Irak ble diskutert. USA hadde på dette tidspunktet bestemt seg for å gå aktivt inn i kampene der, og ønsket å samle en koalisjon. Debatten i mediene om norsk deltagelse begynte rundt datoen for konferansen, og dette var da en naturlig startdato. Den endelige avgiørelsen om å sende soldater 
til Irak for å bidra med opptrening av lokale styrker, ble tatt i Stortinget 29.10.2014. Ryktene om avgjørelsen ble bekreftet på en pressekonferanse 30.10.2014, men styrkene ble ikke sendt før i mai 2015, og debatten fortsatte derfor på dette tidspunktet. For å få med noe av debatten i ettertid ble sluttdatoen satt til 30.11.2014. Tidspunkt for undersøkelsen er altså fra 15.9.2014 til 30.11.2014.

Syria: Forespørselen om deltagelse i Syria kom 3. desember 2015, og første avisoppslag kom 8. desember. Dette er derfor startdatoen for undersøkelsen. Ved oppstarten av vår undersøkelse var en endelig avgjørelse om hvorvidt og hvordan Norge skulle bidra, ikke tatt - det var kun bestemt at man ikke ville sende jagerfly. Denne avgjørelsen ble først meldt i norske medier 19. januar, og sluttdatoen ble satt til noen dager etter dette.

En utfordring med å sette faste datoer for start og slutt er at ikke alt som er skrevet om temaet, vil komme med i undersøkelsen. Det er likevel nødvendig å giøre en form for avgrensning, og det ble naturlig å velge ut de periodene hvor debatten rundt deltagelse var størst, og flest artikler ble skrevet om temaet. Tidsrommet for denne delen av undersøkelsen er derfor 8.12.2015 til 22.1.2016.

\section{Utvalg av aviser for undersøkelsen}

I utgangspunktet ønsket vi å se på dekningen av forespørslene i alle avisene som hadde skrevet om temaet. Gjennom en pilotundersøkelse for å sjekke om tidsperiodene, søkeordene og variablene og kategoriene under dem fungerte, ble vi imidlertid klar over at det eksisterer mange duplikater, da NTB leverer artikler til veldig mange aviser. I tillegg ble det klart at artikkelmengden ble for stor for en undersøkelse av dette omfanget med mindre vi endret søkeordene. Vi bestemte oss derfor for å velge ut fem av avisene med flest artikler om temaet i de to periodene. VG og Aftenposten er Norges mest leste aviser, med nokså ulik målgruppe og profil. Særlig Klassekampen, og delvis også Dagsavisen, har tradisjonelt sett en mer radikal profil enn de to førstnevnte avisene. Dagbladet er på sin side Norges nest største tabloidavis, etter VG. Ved å ta utgangspunkt i disse avisene vil studien kunne gi et inntrykk av hvilket bilde de fleste nordmenn får servert gjennom mediene, samt favne bredden i dekningen fra ulike standpunkter. Problemstilling, bakgrunn og tidspunkt for undersøkelsen er registrert. Retriever er brukt som verktøy for å finne fram til artikler om temaet i de ulike avisene. For å kunne gjennomføre analysen var vi nødt til å avgrense tidsperioder for analysen, finne fram til søkeord og velge ut hvilke aviser vi ønsket å se på. Vi måtte også velge ut hvilke variabler vi ønsket å undersøke. I det følgende vil valgene gjort rundt disse tingene begrunnes, samt utfordringer knyttet til de ulike metodiske valgene bli drøftet.

\section{Søkeord}

Noe av det mest utfordrende med undersøkelsen var å finne fram til passende søkeord i Retriever, for å sørge for at så mange relevante artikler som mulig ble inkludert. Et første søk med ordene «(Norge or norsk) bidrag IS Irak» og «Norge USA forespørsel 
and (IS or Syria)", ga henholdsvis 200 og 53 treff. Etter pilotundersøkelsen ble søkeordene endret til "(Norge or norsk) and (bidrag or militær» or forespørsel) and (IS or Irak)» og "(Norge or norsk) and (bidrag or militær ${ }^{\star}$ or forespørsel) and (IS or Syria)»

Tross at de fleste av artiklene som tidligere ikke dukket opp i søket ble plukket opp med disse endrede søkeordene, vil det alltid være en fare for at noen relevante artikler blir utelukket. Retriever er likevel et foretrukket verktøy for å gjennomføre undersøkelser av norske aviser.

\section{Variabler}

I undersøkelsen valgte vi å se på hvilke kilder som brukes i artiklene, hvilke sjangre de faller innunder, og hvilke tendenser som utmerker seg.

Kilder: Kildene er delt inn i hovedkilde og andre kilder. Hovedkilden er den eksterne kilden som er gitt mest plass ${ }^{2}$. Kildene er plassert inn i kategoriene norsk politiker, utenlandsk politiker, norsk militær, Nato, utenlandsk militær, forsker/ ekspert, organisasjon, mannen i gata, andre medier, andre og - (ingen). I innsendte kommentarer/debattinnlegg/leserinnlegg har forfatterens yrke vært avgjørende for hvordan kilden kategoriseres.

Ved å registrere kilder i de ulike artiklene ble det blant annet mulig å se om det fantes noen sammenheng mellom hvilke tendenser som utmerket seg i avisene, og hvilke kilder som ble brukt. Tidligere undersøkelser på dette området viser at denne typen stoff har en overvekt av elitekilder blant politikere og militære (Nordby 2013, Rossland og Ottosen 2013).

Sjanger: Artiklene er kategorisert etter sjangrene nyhetsartikkel, bakgrunnsartikkel, notis, leder, redaksjonell kommentar og innsendt kronikk/leserbrev/debattinnlegg. Gjennom denne kategoriseringen ble det mulig å se om det fantes noen forskjell i tendensene i for eksempel nyhetsartikler og meningsstoff fra redaksjonen (ledere og redaksjonelle kommentarer). Har avisene for eksempel en tendens til å lene seg mot én side i sitt meningsstoff og en annen i nyhetsartiklene? Ved å se på hvilke tendenser som utmerker seg i lederne i de ulike avisene, vil vi også kunne si noe mer om hvordan avisene faktisk stiller seg til deltagelse i krigen mot IS i henholdsvis Irak og Syria, da det er her de ytrer sine offisielle standpunkter.

Tendenser: Den mest sentrale variabelen å registrere for å kunne svare på problemstillingen var tendensene i de ulike artiklene. Kategoriene som er brukt her, er negativ uten FN-mandat, negativ uansett, positiv med FN-mandat, positiv uansett, nøytral og andre.

\footnotetext{
${ }^{1}$ Pilotundersøkelsen viste at mange artikler ikke dukket opp i søket, til tross for at de var å finne da vi bladde gjennom avisene fra start til slutt. Dermed ble søkeordene endret. Dette ble også gjort for å sørge for at søkeordene for de to periodene ble så like som mulig, slik at resultatene så godt som mulig ville være sammenlignbare.

${ }^{2}$ Der hvor ulike kilder er gitt like mye plass totalt, men én er spesielt framtredende i tittel, ingress og begynnelse av brødtekst, er denne kategorisert som hovedkilde.
} 
Å plassere artikler i tendenskategorier vil være basert på subjektive vurderinger $i$ langt større grad enn for eksempel registreringen av kilder og sjanger. For å styrke undersøkelsens validitet var det derfor viktig med en utførlig beskrivelse av de ulike kategoriene og hva de skulle inneholde. Nøye kategoribeskrivelser ble derfor utarbeidet (se Rudsengen 2016).

Før gjennomføring av pilotundersøkelsen formulerte vi kategoriene kritisk, nøytral, positiv og problematiserende til norsk deltagelse. Disse viste seg imidlertid å være for vide, da vi etter en gjennomgang av artikler fra to dager fra hver periode oppdaget mange flere nyanser i materialet. I tillegg ble andre-kategorien uforholdsmessig stor, og vi ble nødt til å presisere nøyere skillet mellom andre- og nøytralkategorien.

I pilotundersøkelsen utpekte det seg også et fokus på hvorvidt en eventuell norsk deltagelse ville være støttet av et $\mathrm{FN}$-mandat til å gripe inn. I mange tilfeller var støtte/ikke støtte til norsk deltagelse avhengig av om det var/ville komme et slikt mandat. Vi valgte derfor å registrere artiklene som tok forbehold om FN-mandat, da det ville være interessant å se om avisene skrev mer positivt om norsk deltagelse dersom det fantes et $\mathrm{FN}$-mandat ${ }^{3}$. Gjør et $\mathrm{FN}$-mandat for eksempel at pressen kvier seg for å være kritiske, til tross for at det kan være sterke grunner til det?4

Vi vurderte også behovet for en presisering av kategoriene som tar forbehold om FN-mandat, da det i Irak fantes et folkerettslig mandat av et annet slag, gjennom invitasjon fra den irakiske regjeringen. Burde artikler som stilte seg positive eller negative med denne invitasjonen som forbehold, også plasseres i FN-kategoriene, som da måtte utvides til å hete positiv med/negativ uten FN-mandat eller annet folkerettslig grunnlag? Vi endte imidlertid med å droppe dette, da det viste seg at det folkerettslige mandatet som lå i invitasjonen fra den irakiske regjeringen, i liten grad, om i det hele tatt, ble drøftet i avisene i utvalget. En utvidelse av den nevnte kategorien var med det ikke relevant.

\section{Generelle resultater}

I perioden 15. september til 30. november 2014 ga et søk i Retriever på ordene "(Norge or norsk) and (bidrag or militær» or forespørsel) and (IS or Irak)" totalt 234 treff i avisene Aftenposten, Dagbladet, Dagsavisen, Klassekampen og VG. Etter en utsiling sto 96 artikler igjen som relevante for spørsmålet om Norges deltagelse i krigen mot IS i Irak. Av disse var 57 skrevet før Norge bestemte seg for å sende opptreningsstyrker til landet, mens 39 var skrevet etter avgiørelsen.

\footnotetext{
${ }^{3}$ Noe det jo gjorde for eksempel i Libya, hvor norsk presse viste støtte i stor grad i forkant, og kritikken kom først i ettertid.

${ }^{4} \mathrm{Vi}$ syntes også å se tendenser til at eventuell Nato-støtte var avgiørende for om artiklene viste støtte til at Norge burde delta, og vi utformet derfor positiv med Nato-støtte og negativ uten Nato-støtte. Det viste seg imidlertid senere at disse ikke gjorde noe utslag på kategoriseringen av artikler, og de ble derfor til slutt droppet.
} 
Et søk på ordene «(Norge or norsk) and (bidrag or militær ${ }^{\star}$ or forespørsel) and (IS or Syria)» i perioden 8. desember 2015 til 22. januar 2016 ga i alt 133 treff $i$ de samme fem avisene. Etter utsiling av irrelevante artikler sto 39 igjen som relevante for spørsmålet om norsk deltagelse i krigen mot IS i Syria. Det ble altså skrevet en del flere artikler om temaet i forkant av norsk deltagelse i Irak. En grunn til dette kan være at Irak var første sted hvor den USA-ledede koalisjonen mot IS grep inn, og at dette derfor ble gitt mer oppmerksomhet enn inngripen i Syria.

Klassekampen skiller seg ut med klart flest artikler om temaet i begge periodene; 14 om Syria og 37 totalt om Irak, hvorav 19 før og 18 etter avgjørelsen om å sende styrker.

Fordelingen av antall artikler per avis $\mathrm{i}$ de to periodene samlet er presentert $\mathrm{i}$ figur 1 .

Klart de fleste av artiklene i begge perioder går inn under sjangeren nyhetsartikler. Hverken notiser eller bakgrunnsartikler var å finne i noen av periodene, men det ble derimot publisert flere innsendte kronikker/leserbrev/debattinnlegg, ledere og redaksjonelle kommentarer.

Prosentvis fordeling av artikler på sjanger er presentert i figur 2.

Blant hovedkildene dominerer norske politikere, sammen med forskere og eksperter, i begge periodene. I tekstene fra Irak-perioden er langt flere registrert uten kilde, noe som kommer av en større andel meningsstoff i sjangrene innsendte kronikker/leserbrev/debattinnlegg, ledere og redaksjonelle kommentarer i denne perioden. Den totale oversikten over hovedkilder i artiklene, fordelt på de to periodene, er presentert i figur 3 og 4 .

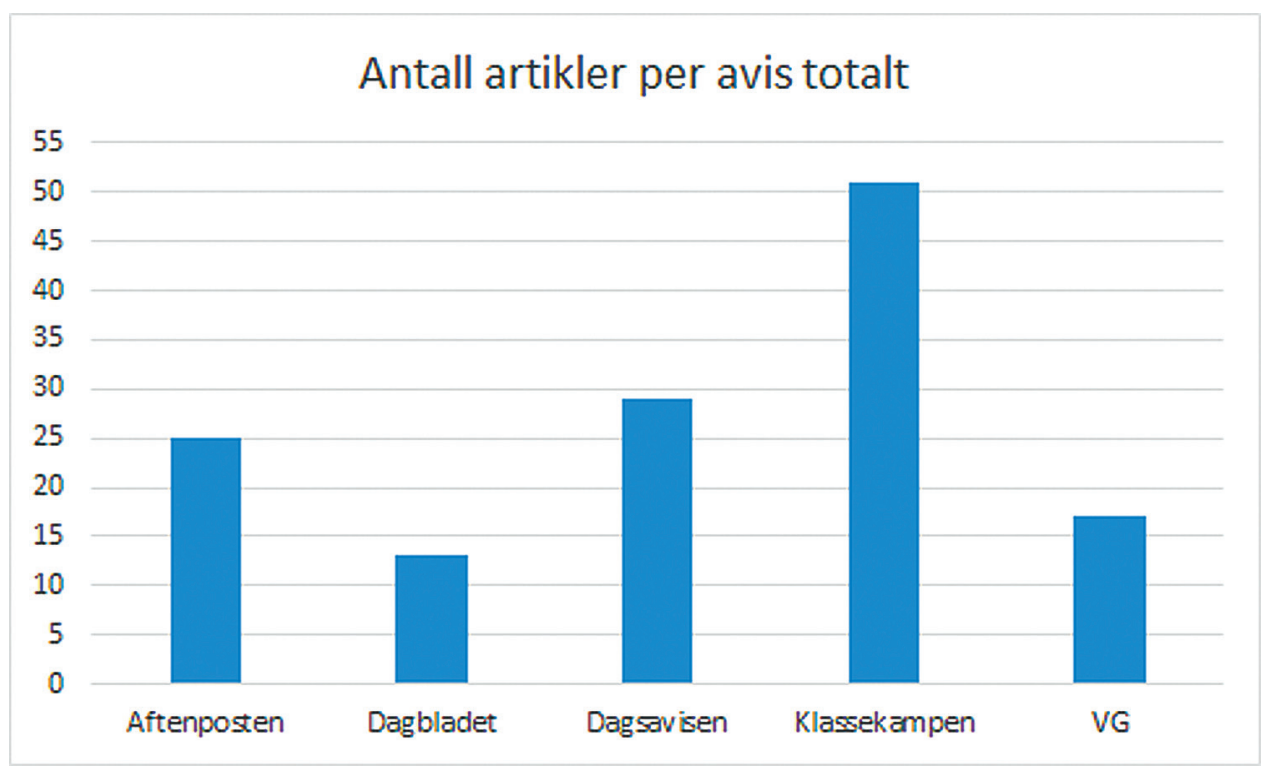

Figur 1. 


\section{Prosentvis fordeling på sjanger}

Nyhetsartikkel
Leder
Redaksjonell
kommentar
Innsendt kronikk/
leserbrev/
debattinnlegg

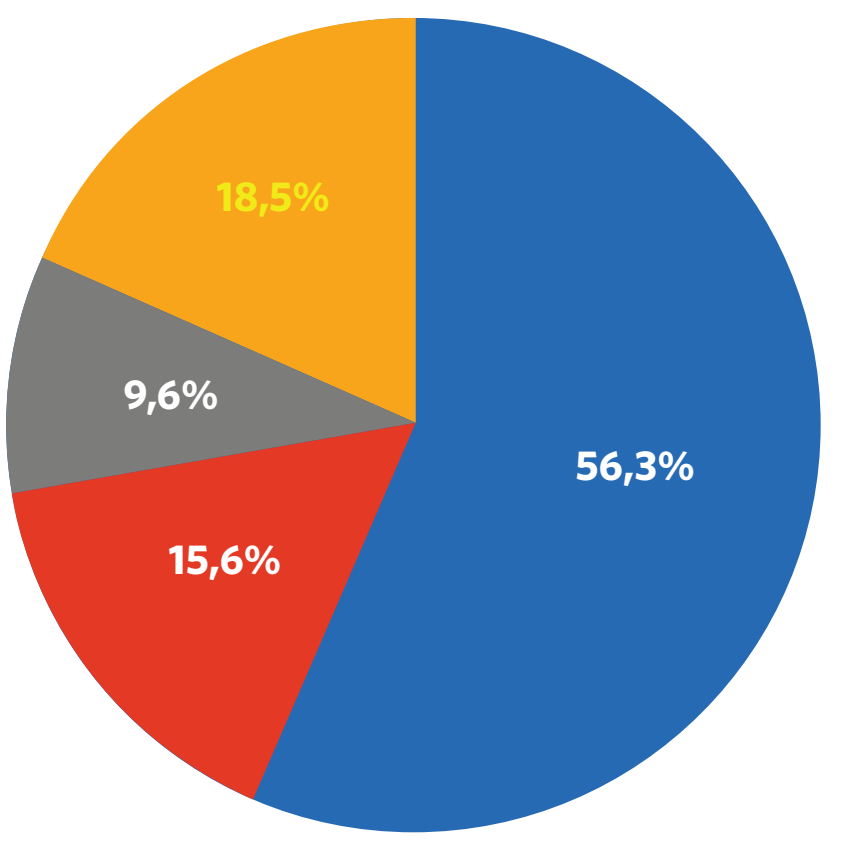

Figur 2.

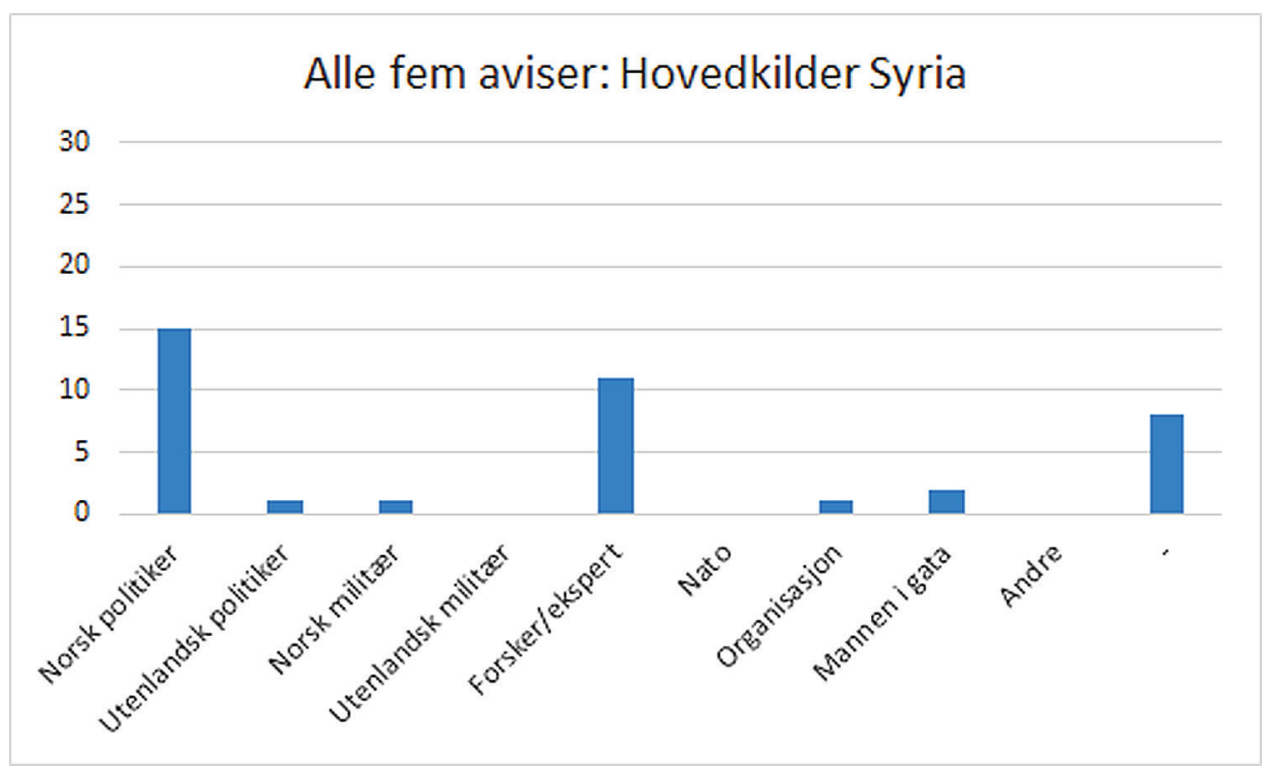

Figur 3. 


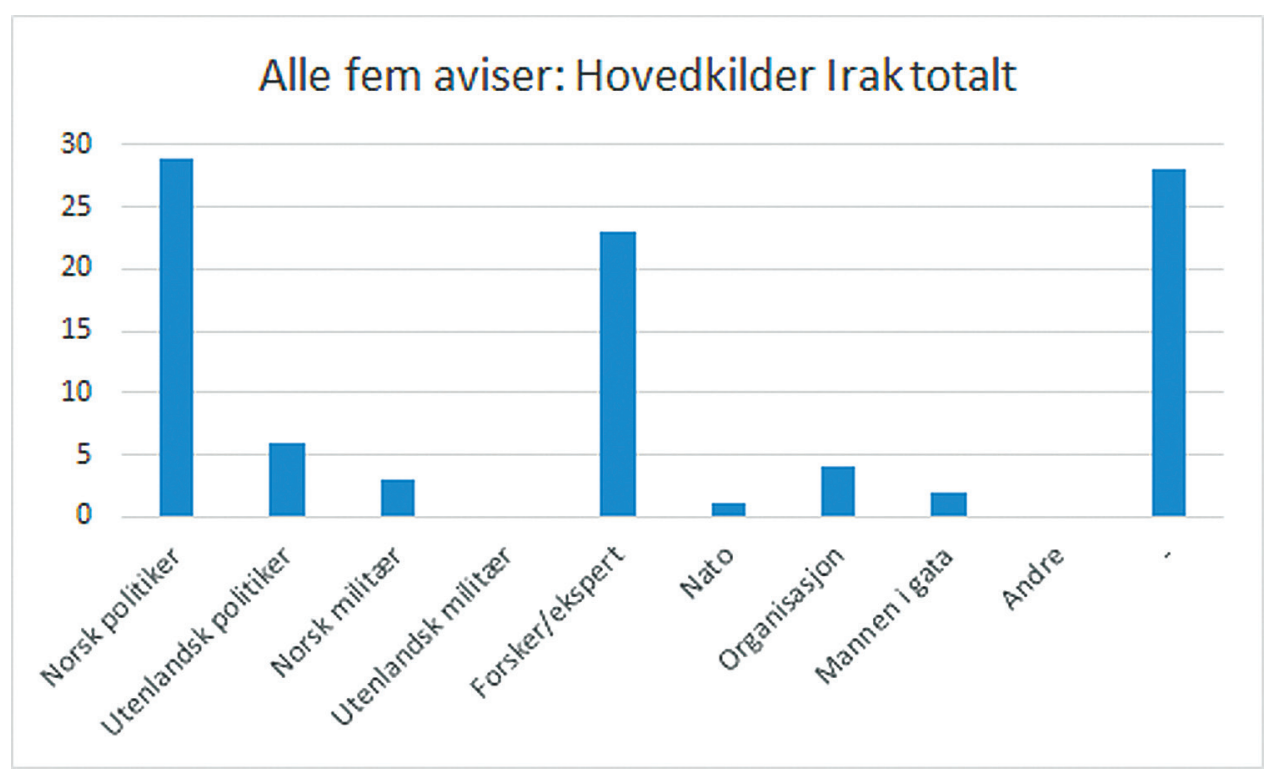

Figur 4.

Også blant andre kilder i artiklene er det klart flest norske politikere som kommer til orde. At denne gruppen dominerer er ikke overraskende, da spørsmålet som er oppe til drøfting, dreier seg om norsk politikk. Det store antallet forskere/ eksperter som også får komme til, kan være et tegn på at avisene søker å sette problemstillingene inn i en større kontekst. At stemmen til mannen i gata er så å si ikke-eksisterende, kan derimot være et tegn på at folkets mening ikke anses som like viktig blant redaksjonene/journalistene - dette til tross for at flere av avisene hadde store oppslag basert på meningsmålinger blant folket. Den utbredte bruken av politikere og forskere/eksperter som kilder stemmer for øvrig overens med funn i tidligere undersøkelser, som har vist at kildeutvalget i norske medier har en tendens til å være dominert av elitekilder (Moen 2013, Nordby 2013).

\section{Forskningsfunn: Tendenser i undersøkelsen}

Tendenser totalt $\mathrm{i}$ alle fem avisene

Langt de fleste av artiklene $\mathrm{i}$ de fem avisene viser en nøytral tendens. Hverken i perioden før opptreningsstyrker ble sendt til Irak eller i perioden hvor deltagelse i Syria ble diskutert, er støtte eller kritikk framtredende om man ser på avisene samlet. I artiklene hvor spesielle tendenser utmerker seg, lener derimot flest seg mot den kritiske siden i Syria-perioden, mens fordelingen mellom artikler med positive og negative tendenser er omtrent lik i perioden før deltagelse i Irak ble bestemt.

Enkelte av de negative artiklene mener en inngripen kan forsvares gjennom et FN-mandat, men dette er et fåtall. Generelt sett utmerker Klassekampen seg som den klart mest kritiske avisen. Andelen artikler med en tendens til å være positive 
til norsk deltagelse i Syria og Irak er nokså lav. Her utmerker imidlertid VG seg som den mest positive til norsk deltagelse i krigen mot IS, særlig gjennom sine artikler i perioden etter at det ble bestemt å sende opptreningsstyrker til Irak.

I perioden Irak før styrker ble sendt er andre-kategorien langt større enn i Syriaperioden. Også her kan det at Irak var første land hvor den USA-ledede koalisjonen grep inn være en faktor; flere av artiklene i denne perioden handlet om koalisjonen og dens inngripen uten at norsk deltagelse ble tatt opp.

Ser man på hvilke tendenser som kommer til uttrykk i artikler publisert etter at det ble besluttet å sende norske styrker til Irak, er bildet et annet. Her viser langt flere av artiklene tydelige positive eller negative tendenser.

En mulig forklaring på dette kan være at en større andel av artiklene fra etter at beslutningen ble tatt, var meningsstoff; 33 prosent av artiklene fra perioden var ledere eller redaksjonelle kommentarer, mot 25 prosent i perioden før beslutningen. Det kan også være at avisene er mer tilbøyelige til å uttrykke klare meninger eller vinkle nyhetsartiklene mot den ene eller andre siden etter at en avgjørelse er tatt, når man har en konkret bestemmelse å forholde seg til.

Fordelingen mellom artikler som viser positive og negative tendenser, er derimot nokså lik. Forskjellen i hvilke tendenser som utmerker seg i de ulike avisene, var imidlertid nokså stor, særlig etter at det ble besluttet å sende styrker til Irak. I det følgende vil tendensene i de ulike avisenes artikler legges kort fram. Hver avis publiserte imidlertid nokså få artikler i de ulike periodene, og hovedtendensene er derfor tillagt mest vekt i denne undersøkelsen.

Tendenser i de enkelte avisene

I perioden før det ble bestemt å sende opptreningsstyrker til Irak hadde Aftenposten 13 artikler om deltagelse i krigen mot IS. Langt de fleste av disse var preget av en nøytral tendens. Kun to artikler uttrykte klare tendenser, hvorav en var negativ og en positiv. Tre av avisas seks artikler fra perioden etter at det ble bestemt å sende styrker, viser positive tendenser, mens ingen av artiklene stiller seg kritiske. Av Aftenpostens seks artikler om Syria uttrykte halvparten en negativ tendens, mens to var nøytrale og en falt innunder andre-kategorien. Grunnet et lite antall artikler er det vanskelig å trekke noen klare konklusjoner om hvorvidt Aftenposten var mer kritiske til inngripen i Syria enn i Irak. Resultatene kan imidlertid tyde på at Aftenposten i større grad publiserte artikler med positive tendenser etter at beslutningen om å sende styrker til Irak ble tatt. Også for denne perioden er utvalget av artikler veldig begrenset, og det er viktig å ikke dra analysen av resultatene for langt, selv om noen antydninger kan sees i materialet. I Dagbladets seks artikler fra perioden før det ble bestemt å sende styrker til Irak, utmerket det seg ingen dominerende tendens. Etter at avgjørelsen om å sende styrker var tatt, publiserte avisen kun to artikler om temaet, hvorav én var kritisk uten $\mathrm{FN}$-mandat og én var positiv uansett. I avisas fem artikler om norsk deltagelse i Syria i perioden for undersøkelsen viser kun én en klar tendens, og da negativ. Tre faller innunder nøytral-kategorien, mens én er plassert under andre. 
I Dagsavisens 13 artikler fra perioden før det ble besluttet å sende styrker til Irak, falt flest inn under andre-kategorien, mens fire av artiklene var nøytrale. Der spesielle tendenser utmerket seg, var de negative, enten uansett eller uten FN-mandat. Av artiklene fra etter at beslutningen var tatt, uttrykte tre av sju negative tendenser, mens en stilte seg positiv og resten var nøytrale eller falt inn under andre-kategorien. Fem av ni artikler i Dagsavisen om deltagelse i krigen mot IS i Syria viser en negativ tendens, mens de fire resterende er kategorisert som nøytrale. Samlet sett kan analysen av Dagsavisens artikler fra de to periodene antyde at avisen i noen grad forholder seg nøytral, men at den der det kommer klare tendenser til uttrykk, lener seg mot å være kritisk til inngripen både i Irak og Syria.

I perioden før det ble besluttet å sende styrker til Irak, viste de fleste av Klassekampens artikler om temaet enten en nøytral eller kritisk tendens. Imidlertid lente tre av 19 artikler seg også mot en positiv tendens i denne perioden. Etter at det ble bestemt å sende styrker til Irak, var Klassekampens dekning sterkere preget av kritiske tendenser, men artikler med andre tendenser forekom også. Også i perioden hvor tekster om norsk deltagelse i Syria ble undersøkt, var Klassekampens artikler preget av nøytrale og kritiske tendenser. Avisa publiserte like mange artikler i disse to kategoriene i perioden, henholdsvis seks i hver, mens kun én av tekstene i avisen viste en positiv tendens.

Norges deltakelse ble nevnt i tre av de seks artiklene VG publiserte om krigen mot IS i perioden før avgjørelsen om å sende styrker til Irak ble tatt. Av disse viste to en positiv tendens og én fremsto som nøytral. I perioden etter at avgiørelsen om å sende styrker var tatt, overtok den positive tendensen helt; alle artiklene som ble publisert, stilte seg positive uansett. Alle var også meningsstoff, enten redaksjonelt eller innsendt. Av de fem artiklene VG publiserte om norsk deltagelse i krigen mot IS i Syria i den undersøkte perioden, viste fire ingen klar tendens, mens én stilte seg positiv uansett.

I forkant av Irak-avgjørelsen og i perioden hvor deltagelse i Syria ble drøftet, kan resultatene tyde på at $\mathrm{VG}$ tenderer til å vinkle sine artikler mot å være positive til norsk deltagelse, men at nøytrale artikler likevel forekommer. Når avgjørelsen så er tatt, får alle artiklene et positivt uttrykk. Dette sammenfaller med en rekke tidligere undersøkelser som viser at norske medier har en tendens til å følge den rådende sikkerhetspolitiske tankegangen i landet - som i stor grad preges av Norges lojalitet til Nato (Ottosen 2001:204). VGs støtte til at Norge bør delta i Irak og Syria, kan kanskje sies å være knyttet til denne lojaliteten, da koalisjonen mot IS er USA-ledet, og USA også er den største bidragsyteren i Nato.

\section{Norges bidrag i krigen mot IS i Irak og Syria på lederplass}

Analysene giort ovenfor viser antydninger til hvordan de ulike avisene har dekket forespørselen om å delta i krigen mot IS i Syria, sammenlignet med hvordan vurderingen av å sende styrker til Irak for å kjempe mot IS der, ble dekket. Analysen viser 
at Klassekampen skiller seg ut som spesielt negativ, mens VG skiller seg ut som veldig positiv. Hvordan ser det så ut når kun det redaksjonelle meningsstoffet undersøkes? Sees disse antydningene der også, eller blir bildet et annet? I det følgende legges tendensene i lederne og de redaksjonelle kommentarene fram for alle fem avisene samlet først, før hver enkelt avis sees nærmere på.

\section{Ledere/redaksjonelle kommentarer $\mathrm{i}$ alle fem avisene}

I tiden før det ble bestemt å sende styrker til Irak, ble i alt 14 ledere og redaksjonelle kommentarer publisert i de fem avisene. Disse fordelte seg nokså jevnt på alle tendenskategoriene som vi ser i figur 5 .

Etter at beslutningen om å sende opptreningsstyrker var tatt, endret bildet i det redaksjonelle meningsstoffet seg noe, og en større andel av artiklene stilte seg positive til det norske bidraget som vi ser i figur 6 .

Den jevne fordelingen i forkant av Irak-beslutningen og skiftet til flere positive artikler i ettertid er imidlertid ikke et uttrykk for at alle avisene er spredt i hvilke meninger de uttrykker før, for så å bli mer positive i ettertid. Forskjellene mellom avisene er store, og det samlede uttrykket er også her et resultat av at enkelte stiller seg veldig kritiske og andre veldig positive.

Avisene hadde samlet sett en nokså liten dekning av forespørselen om å delta i Syria, og en veldig liten del av dette igjen var redaksjonelt meningsstoff. Tallene er for små til å si noe veldig konkret ut fra dem, men av de få artiklene av denne typen i perioden lente de fleste seg mot en nøytral tendens. Der hvor spesielle tendenser utmerket seg, var de negative til norsk deltagelse, som vi ser i figur 7 .

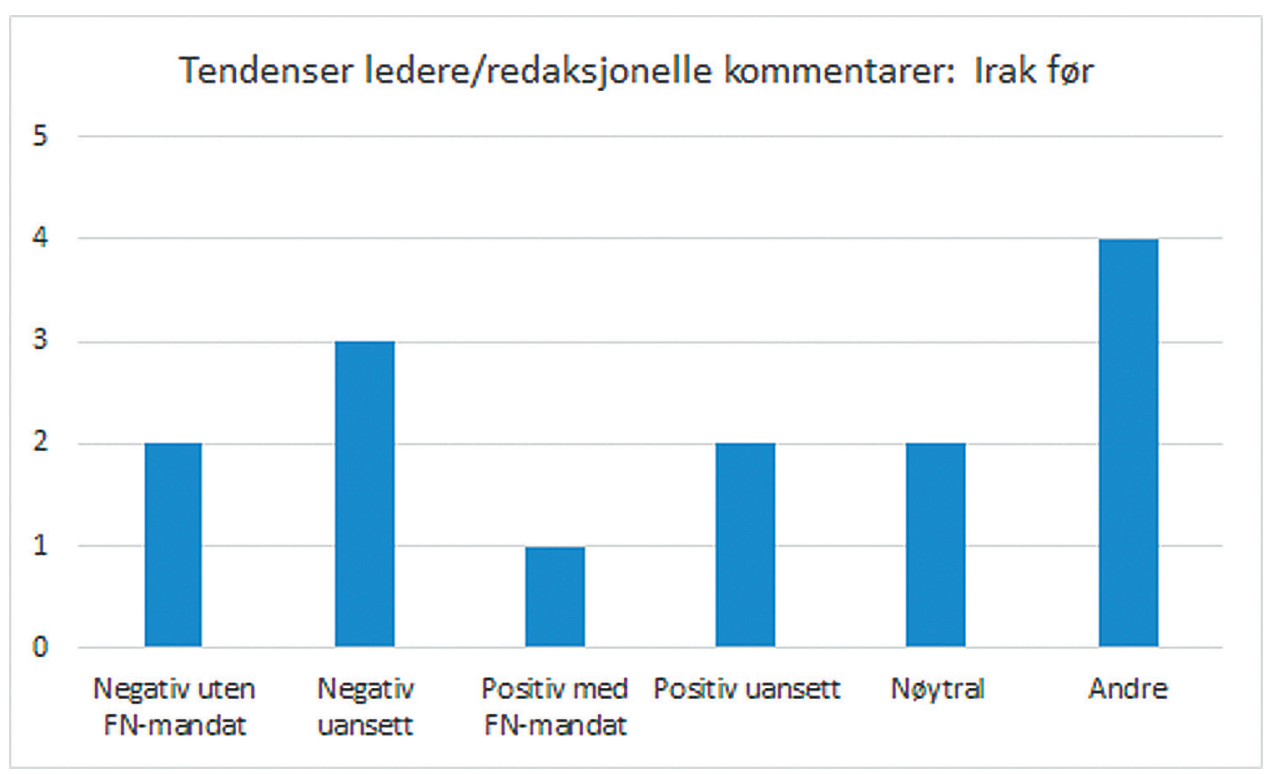

Figur 5. 
Rune Ottosen og Belinda Førandli Rudsengen

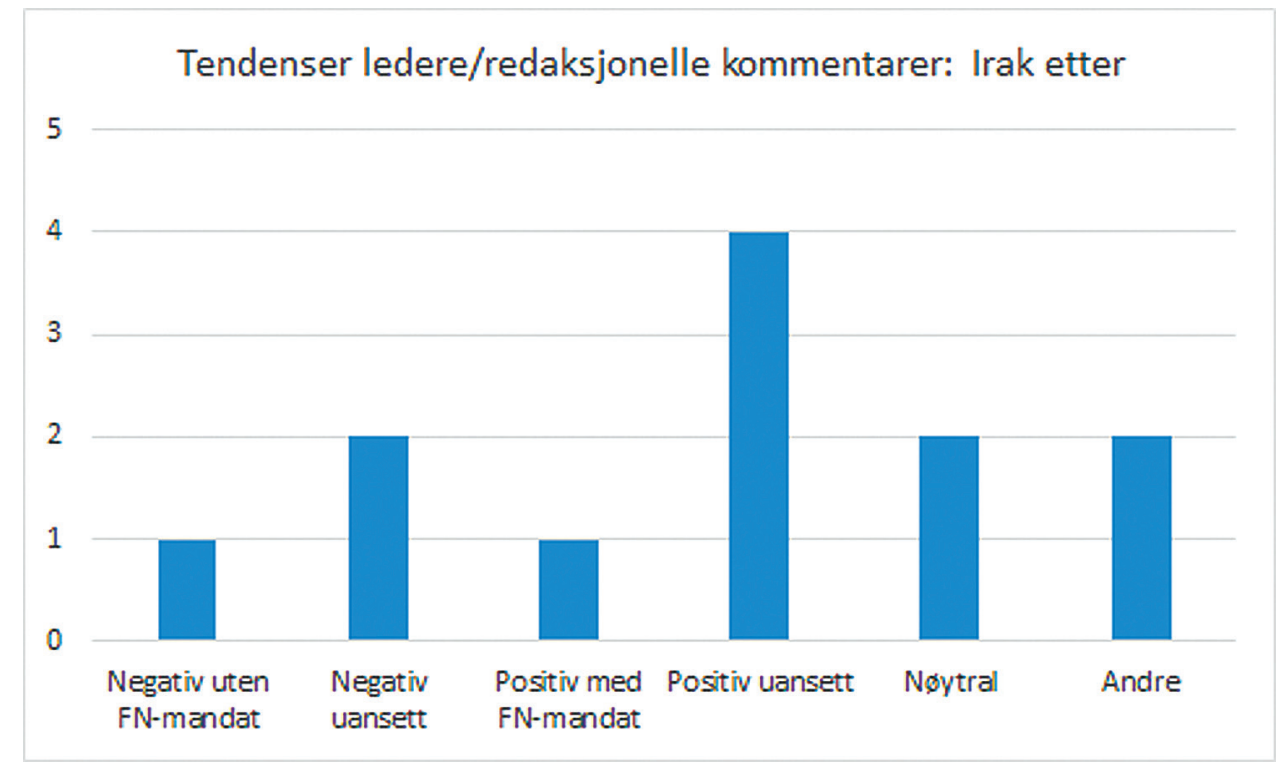

Figur 6.

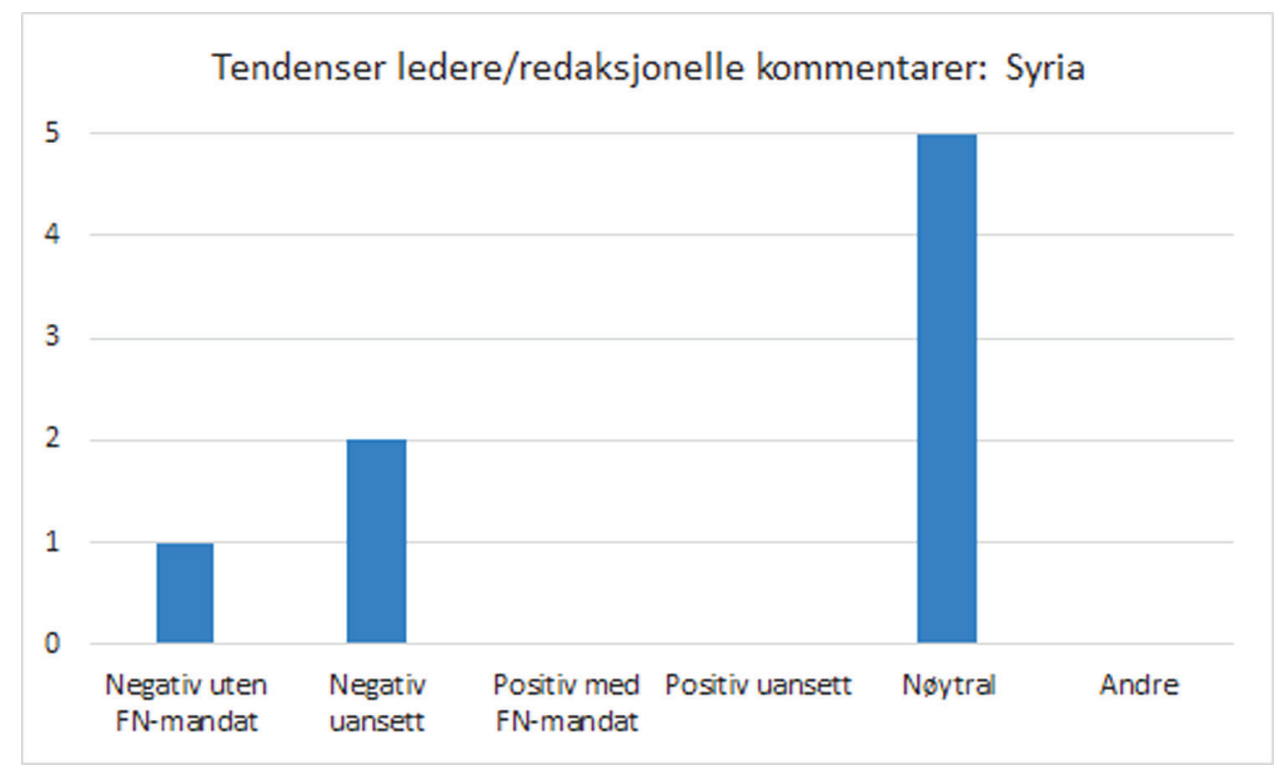

Figur 7.

Ser man på lederne og de redaksjonelle kommentarene, er det interessant nok Dagsavisen og ikke Klassekampen som uttrykker mest skepsis til det norske bidraget, mens VG fortsatt er den mest positive avisen av de fem. Vi ser altså at tendensen til splittelse mellom nisjeavisene og mainstream-aviser fra Libya-dekningen fortsetter. 


\section{Kvantitativ og kvalitativ analyse av ledere}

Ved hjelp av kvantitativ analyse (telling av antall ledere) og kritisk diskursanalyse vil vi nå gå inn i aktuelle lederartikler fra de utvalgte avisene for å se nærmere på argumentasjon og språkbruk i lys av hypotesene for undersøkelsen. Med diskursanalyse bygger vi på Norman Faircloughs teori om at språkhandlinger er diskursive handlinger som inngår i en ideologisk og politisk helhet. Fairclough uttrykker det som «language use as concieved as social practice» (Fairclough 1995:135). Det betyr at språkbruk analyseres i sin sammenheng og inngår i en maktanalytisk kontekst. Vi vil bruke Ruth Wodaks videreutvikling av Faircloughs arbeider, der hun spesielt ser etter historiske referanser $\mathrm{i}$ tekstene. Wodak har i sine arbeider kritisert mediene for å utelate relevante historiske perspektiver i dekningen av sikkerhetspolitikk (Wodak 1996, 2001). I dette tilfellet vil det undersøkes hvilken historisk referanse lederne har til de folkerettslige aspektene ved norsk militær deltagelse, og om det gis referanse til tidligere norske utenlandsoperasjoner i Jugoslavia, Afghanistan, Irak og Libya.

\section{Ledere i Aftenposten om Irak og Syria}

Etter kategorisering av ledere om Irak og Syria fikk vi følgende resultat:

Irak før: Ingen.

Irak etter: 1 positiv uansett.

Syria: 1 nøytral.

Aftenposten hadde to ledere i de undersøkte periodene. Den første dekket utvalgsperioden for vedtaket om å sende norske styrker for å trene irakiske soldater i kampen mot IS. Den stod på trykk 4.11.2014 og hadde tittelen «Riktig med militær innsats mot IS». Den andre dekket perioden med henvendelse fra USA om militært bidrag i Syria. Den stod på trykk 9.12.2015 og hadde tittelen "Militært bidrag må være en del av en bred strategi». Som det går fram av titlene på lederne var den første lederen positiv, mens den andre var mer kritisk.

Lederen med tittelen «Riktig med militær innsats mot IS» har som viktigste argument at «IS er en trussel mot sikkerheten og stabiliteten i en hel region». Aftenposten understreker at en militær støtte må være en del av en større politisk løsning:

«Fremgangen til IS er like mye et symptom på krisen som årsaken til den. Det ville være utillatelig naivt å tro at en militær nedkjemping av IS er ensbetydende med at problemene er løst og regionen stabilisert». Lederen understreker både at dette «ikke er noen form for kulturkamp mellom islam og den vestlige verden», og at dette er en begrenset støtte: «En eventuell opptrapping av bidraget, med innsats nærmere fronten, vil kreve en grundigere debatt i Norge.» Det finnes ingen prinsipiell drøfting av de folkerettslige sidene ved det norske bidraget og eventuelle betenkelige sider ved om norske styrker kan bidra til å legitimere menneskerettighetsbrudd som den irakiske regjeringen er anklaget for å stå bak. I tråd med Ruth Wodaks ønske om å 
trekke inn relevante historiske erfaringer i analysen, refereres det til tidligere norske militære bidrag i utlandet ved at det rettes en advarende pekefinger mot at «Er det noe erfaringene fra Afghanistan viser, er det at krigen ikke kan vinnes uten sivilbefolkningens støtte». Hva dette faktisk innebærer for den nåværende innsatsen mot IS, er uklart. De historiske erfaringene brukes ikke til å trekke inn kritisk refleksjon fra blant annet Godal-utvalget, som stiller spørsmål ved om de norske militære bidragene har bidratt til å løse de humanitære problemene som var norske politikeres erklærte formål med vårt militære bidrag. Det underkommuniseres også at en henvendelse fra USA er grunnen til at vi nå vurderer å sende fly og tropper.

Den andre lederen i Aftenposten er adskillig mer forbeholden med hensyn til et mulig norsk militært bidrag. Forbeholdet kommer fram alt i tittelen: «Militært bidrag må være en del av en bred strategi». Her er USAs rolle tydeligere og mer relevant belyst ved at det nære forholdet til USA understrekes: "Det er ingen grunn til å legge skjul på at dette, som alltid i slike spørsmål, også handler om sikkerhetspolitiske investeringer $i$ vårt forhold til Norges viktigste allierte og NATOs uten sammenligning mektigste land». Denne lederen har i motsetning til den forrige en klar folkerettslig argumentasjon: «Selv om det har kommet en anmodning fra USA, har norske myndigheter et selvstendig ansvar for å vurdere en rekke spørsmål av moralsk, militær og politisk karakter. I Irak har regjeringen bedt om militær bistand fra det internasjonale samfunnet. I Syria er situasjonen en annen, som innebærer at det er nødvendig med en egen vurdering av det folkerettslige grunnlaget. Ikke noe annet land kan vurdere dette på vegne av Norge dersom norske soldater skal delta i krigen.» Etter å ha slått fast tvil om et eventuelt bidrag vil ha folkerettslig dekning, rettes det også en kritikk mot USA, og det er nokså sjelden kost til Aftenposten å være: «Krigen mot IS kan ikke vinnes med militære midler alene og i hvert fall ikke bare med bombing. Problemet med USAs militærstrategi er at moderate opposisjonsstyrker som skal drive IS bort fra de sunnimuslimske områdene, fortsatt ikke finnes». Lærdommene fra Libya og behovet for en grundigere debatt i Stortinget trekkes også fram: «Uansett må vi få en langt grundigere debatt enn da Regjeringen besluttet å bombe Libya i 2011 . Å orientere Stortinget hastig på telefon er ikke noe eksempel til etterfølgelse hvis norske soldater skal settes på krigsfot». Igjen ser vi altså et eksempel på medienes problemer med å dra veksler på de nære historiske erfaringene (Wodak 2001).

\section{Ledere i Dagbladet om Irak og Syria}

Irak før: 1 negativ uten FN-mandat, 1 nøytral.

Irak etter: 1 negativ uten $\mathrm{FN}$-mandat.

Syria: Ingen.

Den samlede innholdsanalysen viste at det ikke utmerket seg noen spesielle tendenser i Dagbladets artikler fra noen av de to undersøkte periodene. I Syria-perioden publiserte avisen ingen ledere om temaet. Det er påfallende at Dagbladet ikke løfter 
behandlingen av dette opp på et mer prinsipielt plan. Dagbladet publiserte derimot tre ledere, hvorav én før og én etter beslutningen om å sende opptreningsstyrker ble tatt, stilte seg kritisk uten FN-mandat, mens den siste forholdt seg nøytral. Interessant er det også at denne kritikken i begge tilfeller tar opp at det mangler et FN-mandat.

I en leder publisert 16.9.2014 skriver Dagbladet: «Norge er spurt om å bidra. Utenriksminister Børge Brende sier at det ikke kommer på tale at Norge bidrar med bakkestyrker eller kampfly. Brendes svar er i tråd med en norsk tradisjon om ikke å engasjere seg militært i oppdrag som ikke har et klart $\mathrm{FN}$-mandat. I koalisjonen av villige, er Norge ikke veldig villig. Det er best slik». Her misbruker Dagbladet en sjanse til å trekke inn nære historiske perspektiver som for eksempel Libya. Dagbladet kunne ha sett sammenhengen mellom kaoset i Libya etter Gaddafi og NATObombingen der Norge spilte en ledende rolle (Ottosen og Øvrebø 2016).

\section{Ledere i Dagsavisen om Irak og Syria}

Irak før: 1 negativ uansett.

Irak etter: 2 negative uansett, 1 andre.

Syria: 1 negativ uansett.

Den samlede innholdsanalysen viste at Dagsavisen hadde omtrent like mange nøytrale og negative artikler til norsk deltagelse i både Syria og Irak. I det redaksjonelle meningsstoffet kommer imidlertid et tydeligere ståsted fram; her er alle artiklene kritiske til norsk inngripen, uavhengig av FN-mandat (bortsett fra én som falt innenfor andre-kategorien).

Dagsavisen er altså kritisk til norsk deltagelse både i den redaksjonelle dekningen og på lederplass. Siden avisen stod på det samme standpunktet gjennom hele den undersøkte perioden, nøyer vi oss her med å gjengi den første lederen som stod på trykk 22.9.2014 under tittelen «Norge i krig»:

«Den islamske stat (IS) er en ekstrem brutal terrororganisasjon. Det er ingen tvil om at disse reaksjonære kreftene må slås tilbake. Men det betyr ikke at enhver militær strategi er fornuftig. En USA-ledet vestlig militær intervensjon i Irak kan få uante konsekvenser, og virke mot sin hensikt. Det er derfor forstemmende hvor lettvint denne saken er behandlet.

Desto mer gledelig er det at SV stilte seg utenfor enigheten på Stortinget. Gjennom åtte rødgrønne år var Stortinget i praksis uten en utenrikspolitisk opposisjon». Selv om erfaringene fra Libya ikke trekkes eksplisitt inn, gjøres det indirekte ved å vise til at SV som støttet Libya-bombingen, nå er i opposisjon: «Torsdag stemte SV mot norsk militær deltakelse og reiste krav om at saken skal behandles i et åpent Storting. Det er et ståsted vi deler. Det er forstemmende hvor lettvint denne saken er behandlet». Her bringer Dagsavisen inn en viss svak historisk referanse, men den kunne vært tydeligere. 


\section{Ledere i Klassekampen om Irak og Syria}

Irak før: 1 negativ uten FN-mandat, 1 negativ uansett, 1 andre.

Irak etter: 1 positiv med FN-mandat.

Syria: 1 negativ uten FN-mandat, 2 nøytrale.

I den samlede innholdsanalysen utmerket Klassekampen seg som mest kritisk til norsk deltagelse i krigen mot IS både i Syria og Irak. Særlig var denne tendensen framtredende etter at det ble besluttet å sende styrker til Irak. I Syria-perioden publiserte avisen imidlertid to ledere om temaet som viste en nøytral tendens, og en som stilte seg negativ uten FN-mandat. I perioden før beslutningen om å sende styrker til Irak var tatt, uttrykte to av lederne en negativ tendens, mens en falt inn under andre-kategorien.

Klassekampens totale dekning stilte seg mest kritisk i perioden etter at beslutningen var tatt. I denne perioden publiserte avisen imidlertid kun én leder, som stilte seg positiv til norsk deltagelse med et eventuelt FN-mandat. Alle de kritiske artiklene fra denne perioden var nyhetsartikler - og motsetningene mellom tendenser i disse og lederne er helt klar.

I lederne som stiller seg negative til norsk militær deltagelse, bruker Klassekampen de historiske erfaringene fra tidligere «out of area»-operasjoner der manglende åpen debatt i Stortinget var en fellesnevner. I en leder publisert 11.12.2015 tar Klassekampen også for seg Stortingets praksis med å behandle norsk krigsdeltagelse bak lukkede dører i den utvidete forsvars- og utenrikskomiteen. Linjene trekkes tilbake til beslutningen om deltagelse $\mathrm{i}$ bombingen av Libya og de folkerettslige aspektene ved denne: «Vi har vanskelig for å forstå hvorfor slik informasjon umuliggjør åpen debatt all den tid det britiske underhuset nylig diskuterte krigsdeltakelse i over ti timer for åpen mikrofon. I dag har vi ingen garanti for at alle innvendinger mot norske bomber i Syria kommer opp i rommet der beslutningen skal tas. I ettertid kan vi heller ikke vite hva som ble sagt der. Fortsatt står det igjen store spørsmålstegn fra krigen i Libya, der Norges bidrag ble godkjent via mobiltelefon. Professor Geir Ulfstein er blant dem som er kritiske til Libya-vedtaket. Av hensyn til folkeretten etterlyser han nå en åpen debatt i Stortinget dersom Norge skal gå inn militært i Syria. De tidligere statsrådene Liv Signe Navarsete (Sp) og Bård Vegar Solhjell (SV) har tatt til orde for det samme. Vi gir dem vår fulle støtte i at et norsk bidrag i Syria må diskuteres åpent i Stortinget, ikke bak lukkede dører».

\section{Ledere i VG om Irak og Syria}

Irak før: 2 positive uansett.

Irak etter: 2 positive uansett.

Syria: Ingen.

VG hadde fire ledere om henvendelsen om norsk militært bidrag til Irak og ingen om et mulig bidrag i Syria. Av alle de undersøkte avisene var det VG som stilte seg 
mest positiv til militær deltagelse i Irak både før og etter at beslutningen om å sende opptreningsstyrker var tatt. Dette er ikke overraskende siden VG også var den eneste norske avisen i dette utvalget som på lederplass støttet USAs invasjon av Irak i 2003. VG rammes av anførte kritikk av manglende historisk kontekst (Wodak 2001), og av kritikken av manglende vilje til å lære av tidligere erfaringer (Ottosen 2009).

Siden alle de fire lederne om Irak var positive til norsk deltagelse, gjengir vi her bare en av dem (den første). Den har en kritisk brodd mot regjeringen Solberg for ikke å være klar nok i sin støtte til et norsk militært bidrag mot IS.

VG viderefører tradisjonen med klar støtte til norske militære bidrag, og er tydelig i sin støtte til tanken om et militært inngrep i en leder publisert 17.9.2014, og skriver: «Norge bør være med på å nedkjempe terroristene i IS. Vi bør bidra militært dersom dette er nødvendig». Det trekkes ingen linjer til erfaringene fra Libya. Problemet slik VG ser det, er først og fremst mangel på besluttsomhet: «Verden, inkludert Norge, har vært for passiv i Syria. Nå tvinges vi til militær innsats mot en gruppe som truer både regionen og verden. At IS har fått etablere seg i Midtøsten skyldes mange faktorer, men en av dem er Vestens manglende vilje og evne til å engasjere seg i konflikten. Dessverre kan dette bety at den innsatsen man nå ikke kommer utenom, blir både mer langvarig og dyrere enn det kunne ha vært. Grunnen til dette er svak og vinglende utøvelse av sikkerhetspolitikk i mange vestlige regjeringer. Også vår egen».

\section{Konklusjon}

Analysen av Aftenposten, Dagbladet, Dagsavisen, Klassekampen og VGs artikler om norsk deltagelse i krigen mot IS i Irak og Syria viser at hypotesen om at avisene var mer kritiske til et mulig bidrag mot IS i Syria enn de var til et mulig bidrag i Irak kan se ut til ikke å stemme helt. Bildet er delt, og vi ser samme tendens som under dekningen av Libya-konflikten at det er et skille mellom mainstream-aviser og nisjeaviser. Det nye er nå at det også er mer nyanser mainstream-avisene imellom ved at Aftenpostens posisjon beveger seg mer i retning nisjeaviser som Klassekampen. Aftenposten og Klassekampen er de eneste som hadde noe større andel kritiske artikler knyttet til Syria enn Irak, men antallet her er så lite at det vanskelig kan sies å bekrefte at hypotesen stemmer for disse to avisene. De dominerende tendensene $\mathrm{i}$ hver avis ser ut til å bestå $\mathrm{i}$ begge perioder, og i stor grad også etter at avgjørelsen om å sende soldater til Irak var tatt. VG var for eksempel positive hele veien, mens Dagsavisen og Klassekampen var kritiske. Den ulike folkerettslige forankringen til bidraget i henholdsvis Irak og Syria ser altså ikke ut til å ha gjort at mediene stilte seg mer positive til inngripen i Irak enn i Syria. Den første hypotesen i denne undersøkelsen ble med andre ord svekket - da tendensen til å støtte inngripen mot IS i Irak viste seg å ikke være der til å begynne med.

Totalt i de fem avisene heller dekningen av begge periodene som nevnt i størst grad mot å være nøytral. Andelen kritiske artikler var noe større i Syria-perioden da flere positivt vinklede artikler ble skrevet før styrkene ble sendt til Irak - men 
denne perioden var heller ikke overveldende positiv; fordelingen totalt ble omtrent lik mellom positive og kritiske artikler. De fem avisene var altså ikke så positivt innstilt til inngripen i hverken Irak eller Syria som man kanskje skulle tro ut fra tidligere undersøkelser, hvor konklusjonene har vist at mediene har en tendens til å støtte den rådende sikkerhetspolitiske tankegangen i landet (se bl.a. Ottosen 2001, van Dijk 1988 og Nohrstedt og Ottosen 2000). At dekningen i etterkant av beslutningen om å sende styrker til Irak fordelte seg jevnt mellom ulike tendenser, er også med på å avkrefte at norske medier har støttet opp under norsk sikkerhetspolitikk og båndet til USA i dette tilfellet.

Mediene støttet i disse tilfellene altså ikke opp under sikkerhetspolitikken og USA-lojaliteten på samme måte som de gjorde for eksempel i forkant av inngripen i Libya i 2011 (Ottosen, Slaatta og Øfstli 2013). Den innledende hypotesen om at norske aviser vil være mer kritiske til deltagelse i militære operasjoner i Syria enn de var da Norge deltok i NATO-operasjonene i Jugoslavia (1999), Afghanistan (2001) og Libya (2011), ble med andre ord styrket. Interessant nok gjaldt den mer kritiske holdningen ikke bare inngripen i Syria, hvor den politiske uenigheten var stor, men også Irak. For å kunne si noe om årsaken til at mediene stilte seg mer kritiske i disse tilfellene, kreves nærmere kvalitative undersøkelser av materialet. Noen av de undersøkte avisene, først og fremst Klassekampen, trekker inn lærdommene fra Libyakrigen, mens VG, som er mest uforbeholden i sin støtte, ikke gjør det på lederplass. Samlet sett har avisene et stykke å gå for å imøtekomme Ruth Wodaks anbefaling om at mediene må bidra til å trekke kritiske veksler på sitt eget lands nære politiske historie.

For å kunne si om mediene har «lært» av tidligere tilfeller hvor de uforbeholdent har støttet militæroperasjoner som senere har vist seg å være lite vellykkede, vil det være nødvendig å se om lignende resultater som i denne undersøkelsen finnes også i dekningen av andre konflikter i etterkant av Libya-krigen. Resultatene i denne undersøkelsen viser imidlertid at mediene i større grad kan sies å ha oppfylt sitt samfunnsoppdrag i dekningen av norsk militær deltagelse i Irak og Syria, ved at både positive og negative røster i større grad kommer til.

\section{Referanser}

Aftenposten (2014) «Syria splitter verdens ledere» 07. 09.2014.

Aftenposten (2015) «Enøyd fra Tvedt om Libya» 19.09. 2015.

Bennett, Lance W., Regina G Lawrence \& Steven Livingston (2008) When the Press Fails: Political Power and the News Media from Iraq to Katrina. London: The University of Chicago Press.

Egeberg, Kristoffer (2017) Fredsnasjonen Norge. Oslo: Kagge forlag.

Eide, Elisabeth \& Rune Ottosen, Rune (2013) Den lengste krigen. Mediedekningen av krigen i Afghanistan. Oslo: Abstrakt forlag.

Fairclough, Norman (2015) Media Discourse. London: Routledge.

Fondenes, Eivind (2013) «Drept i Afghanistan - Chora og de norske soldatene» i Eide, Elisabeth \& Rune Ottosen (2013) Den lengste krigen. Mediedekningen av krigen i Afghanistan. Oslo: Abstrakt forlag (91-108). 


\section{Ambivalent og historieløst? Norske avisers dekning av norsk militcrt ncervar}

Hallin, Daniel (1986) The Uncensored War. Berkeley: University of California Press.

Hammer, Anders Sømme (2010) Drømmekrigen. Oslo: Aschehoug forlag.

Hellestveit, Cecilie (2015) «Syria-krigen og folkeretten.» Klassekampen 15.12. 2015.

Hellestveit, Cecilie (2017) Syria. En stor krig $i$ en liten verden. Oslo: Pax Forlag.

Herman, Edward \& Noam Chomsky (1988) Manufactering Consent. The political Economy of the Mass Media. New York: Pantheon Books.

Klassekampen (2016) «Ut mot 'naiv' Syria-plan» 28.06.2016.

Moen, Gro Mette (2013) «Med norske øyne i Afghanistan» i Eide, Elisabeth \& Rune Ottosen Den lengste krigen. Mediedekningen av krigen i Afghanistan. Oslo: Abstrakt forlag (129-145).

Neumann, Iver B. (2004) «Det er typisk norsk å krige» Arr. Idéhistorisk tidsskrift, spesialnummer «Krig», 16 (2-3): 3-7.

Nohrstedt, Stig A. \& Rune Ottosen (2014) NewWars, New Media and New War fournalism. Professional and Legal Challenges in Conflict Reporting. Gøteborg: Nordicom.

Nohrstedt, Stig A. \& Rune Ottosen (2005) Global War Local Views. Media Images of the Iraq War. Gøteborg: Nordicom.

Nohrstedt, Stig Arne \& Ottosen, Rune (2017) «Sustainable War Journalism and International Public Law» in Berglez, Peter Olausson, Ulrika Ots, Mart (eds.), What is Sustainable fournalism? Integrating the Environmental, Social, and Economic Challenges of fournalism. New York (199-218).

Nordby, Kristin Jonassen (2013) «Informasjonskrigen om Afghanistan». i Eide, Elisabeth \& Rune Ottosen (2013) Den lengste krigen. Mediedekningen av krigen i Afghanistan. Oslo: Abstrakt forlag (147-159).

NOU: 2016:8. En god alliert Norge $i$ Afghanistan 2001-2014.

Ottosen, Rune (2009) VG, Saddam og vi. Et kritisk blikk på nyhetsdekning av krig og konflikt. IJ/Høyskoleforlaget: Kristiansand.

Ottosen, Rune (2002) «Avisbildet av NATOs krigføring på Balkan. Norske avisers dekning av Kosovokrigen i 1999». HIOA-rapport nr. 8.

Ottosen, Rune (2001) «Journalistenes konfliktfylte lojalitet. Et historisk perspektiv på krigsdekningen i norske medier» i Eide, Martin (red.) Til dagsorden. Oslo: Gyldendal norsk forlag (197-224).

Ottosen, Rune, Tore Slaatta \& Sigurd Øfsti (2013) «How they missed the big story: Norwegian news media and NATO's military operation in Libya». In Conflict $\mathcal{E}$ Communication Online. Vol. 12. (1) http://www.cco. regener-online.de/2013_1/pdf/ottosen_et_al.pdf nedlastet 23.04.2016.

Ottosen, Rune. \& Sjur Øvrebø (2016) «Who's to blame for the chaos in Syria? The coverage of Syria in Aftenposten, with the war in Libya as doxa in Orgeret, Kristin \& William Tayeebwa (eds.) Fournalism in Conflict and Post-Conflict Conditions - Worldwide perspectives. Gøteborg: Nordicom (63-80).

Regjeringen.no (03.03.2015): «Norske soldater til Irak». URL: https://www.regjeringen.no/no/aktuelt/norskesoldater-til-irak/id2398389/ [Lesedato: 17.10.2017]

Rossland, Irene \& Rune Ottosen (2013) «Norsk godhetsregime og Aftenpostens krigsdekning i Eide, Elisabeth \& Rune Ottosen, Den lengste krigen. Mediedekningen av krigen i Afghanistan. Oslo: Abstrakt forlag (161-179).

Rudsengen, Belinda Jørandli (2016) «Norske styrker til krig mot IS i Irak og Syria? En analyse av dekningen av fem norske aviser». Vit. ass.-rapport Institutt for journalistikk og mediefag, Høgskolen i Oslo og Akershus våren 2016.

Haga Skånland, Øystein (2009) «Norsk utenrikspolitikk i fredens tegn», Internasjonal politikk 67 (3): 32-48.

Tvedt, Terje (2015) "Tausheten om Libya», Nytt Norsk Tidsskrift, 32 (3): 205-216.

Tvedt, T. (2015b) «Den politiske eliten ante ikke hva de gjorde da de gikk inn for å sende F- 16-fly til Libya»| Aftenposten, 15.09. 2015.

Tunander, Ola (2012) Libyenkrigets geopolitik: Humanitär intervention eller kolonialkrig? Lund: Celanders Förlag.

Ulfstein, G. (2015a) «Folkeretten må utredes før krigføring». Aftenposten 22.09. 2015.

Ulfstein, G. (2015b) «Vil norsk bombing i Syria være folkerettslig» Aftenposten 22.11.2015.

Van Dijk, Teun (1988) News Analysis - Case Studies of International and National News in the Press. New Jersey: Lawrence Erlbaum.

Wodak R (1996) Disorders of Discourse, Harlow: Longman.

Wodak R (2001) Critical Discourse Analysis in Postmodern Societies. Special Issue of Folia Linguistica XXXV/12, Berlin: De Gruyter. 


\title{
Om forfatterne
}

Rune Ottosen er professor emeritus i journalistikk ved OsloMet - storbyuniversitetet. Han har publisert en rekke bøker og artikler om mediedekningen av internasjonale konflikter og pressehistorie.

Belinda Jørandli Rudsengen har en mastergrad i journalistikk fra OsloMet storbyuniversitetet. I masteroppgaven undersøkte hun dekningen av den folkerettslige forankringen til det norske Syria-bidraget. Hun jobber i dag som journalist i Oppland Arbeiderblad, og dette er hennes første publiserte fagfellevurderte artikkel.

\begin{abstract}
English
This article describes how the five Norwegian newspapers VG, Aftenposten, Klassekampen, Dagsavisen and Dagbladet covered the US request for participation in the war against IS in Syria in 2015, compared with the coverage of the decision to send Norwegian soldiers to train Iraqi forces in the war against IS in Iraq in 2014. The time of the analysis is 15 September-30 November 2014 (Iraq) and 8 December 2015-22 January 2016 (Syria). The method is quantitative content analysis based on assessing whether the articles are "negative without UN mandate", "negative anyway", "positive with UN-mandate "," positive anyway "," neutral "or" other "." A genre analysis has also been conducted with emphasis on differences between managers, comments and news articles. Finally, a qualitative analysis of the management articles was conducted using critical discourse analysis. The hypotheses is that Norwegian newspapers will be more negative as regards participation in Syria than in Iraq, and than in previous events such as participation in foreign operations in Yugoslavia (1999), Afghanistan (2001) and Libya (2011). The survey shows that the hypotheses were only partially confirmed.
\end{abstract}

Keywords: IS - war on terror · Syria · Iraq · international law 